\title{
Strategies in Online Speaking Classroom in the Time of Covid-19: A Descriptive Study at Tertiary Level
}

\author{
Zelvia Liska Afriani \\ IAIN Bengkulu \\ Zelviaafriani20@gmail.com \\ Valisneria Utami \\ IAIN Bengkulu \\ Valisneriautami@gmail.com
}

\begin{abstract}
Recently, the Covid-19 pandemic has transformed teaching and learning into a virtual model, which demands teachers to find their best strategy. This study aims to analyze the strategies applied by teachers at the tertiary level in the time of Covid-19. The researchers employed a descriptive research design conducted in one of the Islamic universities at Bengkulu. The subjects were two English as a foreign language (EFL) teaching staff who taught speaking skills at the beginner level. The data was obtained through a semi-structured interview. The observation was also done during one semester, where the researchers took part in the online classrooms. After the data was collected, the researchers analyzed the data by following some steps: (1) data reduction, (2) data display, and (2) conclusion drawing/verification. The findings revealed that the English teachers used several teaching-speaking skills integrated with social media and mobile phone applications to be accessed easily. The strategies are lecturing, role-play, online group discussion, simulation, and drilling. They are blended with WhatsApp Group, Google Classroom, Zoom, and Instagram. Even though the learning process can be managed in this pandemic, face-to-face learning is still favorable.
\end{abstract}

Keywords: strategies, speaking classroom, covid-19 


\section{INTRODUCTION}

The world is currently facing a pandemic caused by SARS-CoV-2 (Coronavirus) and its infection called Corona Virus Disease 2019 (Covid-19). This viral infection was initially discovered in Wuhan, China, in December 2019 and has spread rapidly to various parts of the world. Based on the data reported by the Covid-19 Task Force, dated January 31,2021 , it has been confirmed that the virus has infected 1.078.314 people in Indonesia with a death rate of 29.998 people, and 873.221 people have successfully recovered (Moerti, 2021). This pandemic is not only affecting the health sector but all aspects of life, including education from elementary to higher education level. Consequently, the students are "forced" to study from home because face-to-face learning is assumed can prevent the transmission of Covid-19.

Due to the condition above, The Government of the Republic of Indonesia immediately issued Government Regulation (PP) No.2 of 2020 concerning Large-Scale Social Restrictions in the Context of Accelerating the Management of Covid-19 and Presidential Decree of the Republic of Indonesia No. 11 of 2020 concerning the Determination of the 2020 Corona Virus Disease Public Health Emergency (Covid-19). This regulation requires immediate adaptation, which makes students and teachers have to carry out the learning process online.

According to King, Richmond, Young, and Schrader (2001), "Distance learning is improved capabilities in knowledge and/or behaviors as a result of mediated experiences that are constrained by time and/or distance such that the learner does not share the same situation with what is being learned." During the Covid-19 epidemic, the online learning system, or E-Learning, has favorably contributed to the continuation of the teaching and learning process (Taufik, et. al, 2020). Technical media, particularly technology, become the main inclusion in distance learning to bridge teachers and students in different places and times (Saykıll, 2018; Espino-d \& Fernandez-caminero, 2020; Mishra et al., 2020). Thus, teachers must have adeptness to integrate technology as an instrument to ease the learning activities in class.

A teacher plays a learning agent and must have several competencies to create a good classroom atmosphere, either face-toface or online learning. Government Regulation No. 19 of 2005 mentions that the teacher must possess four competencies: pedagogical competence, professional competence, personality competence, and social competence. One of the important aspects is pedagogical competence. Syahrial et al. (2019) explain that teachers' pedagogic competence focuses on the ability of how teachers design learning 
materials, create learning media and discover teaching techniques including models, methods, and strategies. In this competence, one thing to emphasize is that the teacher can develop the students' maximum potential. It can be started from a teaching strategy.

According to Foshay (1975), a strategy is a general pattern of a series of activities that must be carried out to achieve specific goals. It is said to be a general pattern because a strategy, in essence, has not led to practical matters, is still in the form of a plan or a comprehensive picture. Meanwhile, to achieve the goals, strategies are drawn up for specific goals. As proposed by Wehrli and Nyquist (2003) several teaching strategies can be implemented in the classroom, such as brainstorming, problem-solving, simulation, demonstration, games, large-group discussion, lecturing, role-play, direct-contact, and one-toone strategy. Each of these strategies may assist students and teachers in achieving the learning goals, with the provision of it being applied properly and accurately.

Furthermore, the teacher's appropriate strategy will promote students' self-regulatory learning (Kistner et al., 2015), especially in current conditions, where the students are asked to be autonomous learners at home. Hence, she/he needs to plan, choose and determine the right teaching and learning strategy in this pandemic. The determination of the strategy used will determine how learning activities are carried out. It will also reveal which direction the learning process will lead.

In this study, the researchers focused on investigating the teachers' teaching strategies, commonly known as lecturers at the tertiary level. Effective strategies used by teachers in teaching speaking skills are essential for students to overcome their learning difficulties. Those strategies can help them improve their fluency and accuracy. Each teacher may use different strategies to improve the ability of students to speak. After practicing the strategies, the teacher can see how students understand the language and can benefit from understanding what makes them successful and unsuccessful, and set up a milieu in the classroom to implement successful strategies (Brown, 2000).

After all, the strategy applied must be relevant to their needs and interests, let alone in this pandemic, which asks the students and teachers do a virtual learning process. In the search for the best teaching-speaking strategy model used by English teachers in the time of Covid-19 at the tertiary level, the researchers decided to analyze the 
teaching-speaking strategies based on Wehrli and Nyquist's guidelines. This paper was intended to describe what strategies were used and analyze their implementation during one semester.

\section{THEORETICAL FRAMEWORK}

\section{Strategies in Teaching Speaking}

Speaking is one of the productive skills that must be mastered by EFL students. This skill is very vital since the aim of learning a language is to be able to use it as a tool to communicate properly and accurately. Speaking, being the initial expression of language has been positioned as a critically essential skill that should be taught with suitable methods. The objective of training speaking should be to improve communication efficiency (Gusmuliana, et.al, 2020). The communication that occurs throughout the discussion must be communicative for the speaker and hearer to grasp what is being said. In daily conversation, which includes conversations that occur in the workplace, such as those between a client and a clerk, a buyer and a seller, a student and a teacher, and other types of discussion fields (Syafryadin, et. al, 2020). In reality, the students still find a way to become proficient in speaking English because most of them argue that it is a difficult skill. The role of English teachers is critically needed in this situation, especially to discover appropriate strategies in the classroom. The implementation of suitable strategies in the class will hopefully assist the students to be able to speak English fluently.

A teaching strategy can be described as a plan for delivering a lesson that includes teaching objectives and procedures for implementing the strategy. Wehrli and Nyquist (2003) list several speaking strategies that can be applied by the teachers. Those are explained below:

\section{a. Brainstorming}

The brainstorming method is a strategy of teaching used in group discussions to generate new ideas, thoughts, or ideas by bringing up a problem to students by the teacher, then students answer or express opinions or comments so that the problem develops into a new problem. It is normally done to direct learners to the materials that will be taught so that they have a basic understanding of what they will be learning. According (Naser \& Almutairi, 2015), brainstorming improves teamwork and efficiency among students and develops creative problemsolving skills. It also enables students to produce as many ideas as possible in a short period. 
b. Problem-Solving Strategy

Problem-solving strategies are strategies that teach students how to get solutions to problems that arise. Hence this strategy was initiated with an uneasiness of the problem (problem) that must be solved. Problem strategy solving (problem-solving strategies) is not just a teaching strategy but also is a method of thinking because in problem-solving, other methods can be used, starting with looking for data to concluding. Problem-solving learning can help students develop critical thinking skills while also improving their speaking fluency. A problem-solving strategy allows students to work together as a group to solve a problem that the teacher has posed. It also boosts students' motivation. Learners are encouraged to practice speaking by using English to solve real-life problems, which will lead to them not only thinking critically, but also learning as a team with others (Belecina., \& Ocampo, 2018)

c. Simulation

Simulation is a strategy given to students so that students can use a certain set of facts, concepts, and strategies. It provides opportunities for students to interact so that they can reduce fear. This strategy tends to be more dynamic in responding to physical and social symptoms because through this method it is as if students are doing things that are real. By simulating a case or problem, a person will more animate his existence. So it is appropriate to use it in teaching speaking skills as it can improve students' oral fluency. In a simulation, learners take on the role of themselves in a specific situation, such as attending a business meeting or reserving a table in a cafeteria, among other things. Vlachopoulos \& Makri (2017) identified several benefits of incorporating simulation into the classroom: it is enjoyable and motivating, it encourages reluctant learners to speak, and it provides a wider range of language as it is used in the real world.

d. Demonstration

The demonstration is a very effective strategy to improve speaking skills because it helps students to find answers on their own based on facts or correct data. It presents lessons by demonstrating a particular process, situation, or object, either actual or just imitation. As a presentation method, a demonstration cannot be separated from verbal explanations by the teacher. Even though in the demonstration process the role 
of students is only paying attention, demonstrations can present more concrete learning materials. In the learning strategy, demonstrations can be used to support the success of expository and inquiry learning strategies.

e. Games

Games are a great way to keep students engaged in language learning, particularly when it comes to improving their speaking skills. This strategy is primarily inclusive in that it includes all students and can accommodate a variety of learning styles and personalities. Hadi (2015) states that when a lesson involves a game, it allows the teacher to effectively assist learners in learning new forms and lexis. It should also provide praise and motivation to help students stay motivated in their studies. Aside from all of this, keep in mind that games should be as short as possible because students typically only have a small amount of time to pay attention.

f. Discussion

Discussion is one of the teaching strategies that can be used in learner-centered learning situations. Learners may express their thoughts and feelings while also listening to the perspectives of others by engaging in a broad group discussion. In this pandemic, the discussion runs online through WAG or zoom meetings. Gao (2014) states the emphasis of online conversation tends to stay on surface levels, such as exchanging or comparing content, rather than delving deeper into issues like negotiating definitions, synthesizing, or applying newly acquired knowledge.

g. Lecturing

Lecturing is a traditional teaching strategy that is often dismissed as antiquated. However, some teachers continue to use this method of instruction. A lecture is mainly a didactic presentation of knowledge to a wide number of people, often through the use of audiovisual aids.

h. Role-Play

Role-playing is a strategy that encourages students to explore practical scenarios by engaging with others in a safe environment to gain experience and try out various techniques. Participants may play a role that is similar to their own (or one that they may play in the future), or they may play the opposite side of the conversation or interaction, depending on the nature of the activity. In the classroom, it provides variety, a change of pace, and opportunities for a lot of language production while 
still being a lot of fun. It can be a normal part of the class rather than a one-time occurrence. It can be very good if the instructor believes the activity will work and provides the required support.

i. Direct Contact

Classroom teachers who use a direct-contact teaching strategy invite a guest speaker to speak while they are teaching. Direct interaction with native speakers of the target language provides learners with an experience as well as a trigger for developing a positive attitude toward the target language and its speakers. Teachers can invite native English speakers to facilitate speaking by allowing students to practice their English with them.

j. One-to-one Strategy

Teaching one-to-one, according to Harmer (2007, p.122), entails "an individual learner working alone with a teacher over a period of hours or weeks." It's commonly referred to as "individual classes." Since a teacher focuses solely on one learner in a oneto-one class, the learner has a better chance of doing all of the speakings than in a large class where the teacher would divide his attention among several learners.

\section{RESEARCH METHODOLOGY}

This study employed a descriptive research design. According to Nassaji (2015), "The goal of descriptive research is to describe a phenomenon and its characteristics." This method is considered appropriate in this study because it aims to describe the phenomena in class regarding the strategies used by English teachers, commonly called lecturers, in teaching speaking skills during the Covid pandemic. The observation was done for one semester from September 2020 to January 2021 by looking at the classroom interaction in four classes. Two English teachers at one of the Islamic universities in Bengkulu were interviewed to get the information needed with a semi-structured interview. The theory used in this study is from Wehrli and Nyquist (2003). They taught speaking skills at the beginner level (semester one and semester three). After the researchers took the data from the observation and interview, they were then analyzed using Miles and Huberman's theory. It consists of three activities: data reduction, data display, conclusion drawing/verification. 


\section{RESULTS \& DISCUSSION}

The observation was done in September 2020 where the researchers attended the virtual classroom for speaking class. It was found that the teachers used some technology applications for the learning process, such as WhatsApp Group (WAG), Google Classroom, and Zoom. In the first meeting, they started the course via zoom. Since this is the first meeting for them, the students and the teachers introduced themselves. Then, it was continued by reading the course syllabus for one semester.

During several meetings, the teachers felt that the zoom application is not satisfying enough in helping the learning process due to the connection that most students have. Most of them do not have the right signals because they live in rural areas. Then, this demands the teachers to find other ways to support the learning process. Hence, the teachers added some applications such as WAG and Google Classroom. They decided to make a zoom meeting once in three weeks to evaluate the topics shared and learned in the online group.

Google Classroom is used as a medium for teachers to ask students to collect their tasks. The tasks were given based on the instructions delivered via WAG. In Google Classroom, students can submit their videos or recording regarding the topic in the course syllabus. They can also see the grades for each assignment they have fulfilled. So, it is considered highly transparent.

The researchers also found that the teachers' strategies can be seen from the way they asked the students to speak up in the online classroom. Based on the guidelines proposed by Wehrli and Nyquist, some strategies implemented were lecturing, role-play, online group discussion, simulation, and drilling. Each strategy is explained below:

a. Lecturing

Lecturing is a conventional strategy mostly used by teachers in the classroom, known as the teacher-centered method. Based on the virtual class observation, it was revealed that those two teachers use this strategy in teaching English speaking to their students. This strategy refers to learning situations in which the teacher determines the subject matter that students study and how they study it, i.e., when, where, how, and at what speed they learn it. Generally, when classes are classified as teacher-centered, the teacher dominates the classroom, and the students spend most of their time listening, taking notes, and responding to questions the teacher explains or asks.

Kaur (2011) emphasizes that lecturing aims to support the course's objectives by explaining the materials taught in detail, can be 
by giving examples of situations, not presenting useless information to students who are just sitting there passively listening to the teachers.

Both speaking teachers used this way at the beginning of the class to present new subject matters and respond to the expressions of students who still do not understand the material yet. They also combined it with a question and answer session, tasks or exercises, and discussion. The researchers did not find the unusable explanation in the class because they focused more on practicing the students' performance in their English ability. However, some students sometimes get bored and still did not get the point of the explanation. The researchers assumed that the distance learning process could cause it. Possibly, the students cannot fully concentrate in the classroom because they sometimes do another task while they attended the zoom meeting, for example: using a handphone, babysitting their sisters, or other side house jobs.

b. Role-Play

Based on the interview with both teachers, they chose to roleplay in the virtual speaking class because it helps the students overcome their confidence in speaking. It also allows them to practice their language ability with some specific topics given. Here are some situations in the speaking classroom:

\section{Excerpt 1}

T1: You can see a picture that I have screen-shared. It is a map. Now, please make a role-play where $A$ is someone who gets lost and $B$ is someone who gives the information.

(Teacher 1, Meeting 5, Topic: Asking for Directions)

\section{Excerpt 2}

T2: Your today's assignment is to make a video with peers about how to make a telephone call. You may use video-call and record it. Don't forget to submit it in our Google classroom!

(Teacher 2, Meeting 2, Topic: How to Make Telephone Call)

The statements above were extracted based on the transcription from T1 (Teacher 1) and T2 (Teacher 2). The topic was about asking for directions and telephone calls. In T1's class, the teacher showed a city map by sharing the screen via zoom. The students then have to give their voice based on the teachers' instructions by doing a role-play with their classmates. Meanwhile, in L2's class, she asked the students to create a 
video about making a telephone call with their friends as a task. Then, they have to upload it to Google Classroom.

Based on the interview with T1 and T2, they said that using this strategy can improve speaking skills because students can speak even when they are in an online class. The role-play method was chosen because the learning process involved many students directly so that they enjoyed learning and practiced more in their ideas. Besides, the teachers can also assess whether students understand the material being taught or not. This can be seen from the fluency of students in practicing the commands they are told to do. Both teachers argue that fluency is the main thing that beginner-level students must-have rather than accuracy.

c. Online Group Discussion

Online Group Discussion becomes an option for the teachers in the virtual class. Due to the limited time that the teachers have, they required the students to discuss the materials in WAG and monitor the activities.

The researchers know this strategy from the conversation between teacher 2 and the students below:

\section{Excerpt 3}

T2: Next week, you have to present the current condition in Indonesian during Covid-19. You may talk about health, economy, education, climate change, or the environment. Please discuss it in our WA Group if you have any obstacles in deciding the topic you want to explain.

In the interview, teacher 2 said that online group provides students' interaction between student and student or teachers and students. Even though they did not meet their friends and teachers directly, they could still work together to elaborate their ideas virtually by using a voice note or typing it in WAG. The teachers can also assess students' participation in the group whether they involve actively or not.

In this online group, not only students' speaking skills can be measured but also their writing skills, mainly in grammar and punctuation. In addition, another advantage of this strategy is that the teachers can fix students' mistakes or errors when they speak through voice notes. 
On the other hand, teacher 1 did not use this strategy in class because she usually used WAG just as a tool to give information to students about the class schedule, attendance list, or class assignments.

\section{d. Simulation}

In evaluating the students' performance toward their speaking skills, the teachers ask them to make a video regarding the topics given. They did it for the mid-term test and final exam. The procedures were that teachers gave some themes based on the syllabus (The materials learned in class). Next, they have to make a simulation before making a video to be more fluent because it would be graded. For example, they are going to a restaurant and want to order food and drinks. Then, they must play themselves in that situation. After they created the video, the projects must be uploaded to social media, in this case, Instagram.

Instagram was chosen because all of the students in class use this application in sharing their activities. Hence, the students were asked to upload it there. The aim is to positively affect other people who watch it where they can learn some new English vocabulary, phrases, or pronunciation by looking at the videos shared by the students as explained by teacher 2 below:

\section{Excerpt 4}

T2: My reason why choosing social media platform is that the majority of my students have the account so why not utilize it as media for learning? They can share their videos, their friends can give comments, or maybe learn something new from the video. After all, perhaps, talking through video and social media might put them in a less pressured environment compare to talking directly to their lecturer.

\section{e. Drilling}

The next strategy implemented by the teachers is drilling. This method can help students improve their speaking skills due to continuous practice. Examples of implementing this strategy in the classroom can be seen in the observation results below:

\section{Excerpt 5}

L1: Look at the screen! There is a family. They want to buy tickets for a holiday. Please pay attention to what the ticket seller said. 
TS: How many tickets do you want to buy? - The teacher stopped the video.

L1: Now, repeat what she said. Let's say you are a ticket seller.

Repetition Drill

Ss: How many tickets do you want to buy?

L1: All right, now take a look at the numbers of that family. We'll continue the video.

TS: Three adults and 2 children to Monas, please.

L1: What if 5 people, 3 adults, and 2 children. They want to go to Anyer Beach.

Ss: Three adults and two children to Anyer Beach, please. (Most of the students say loudly together)

(The teacher continued the video)

L1: Well, Now, I'll give you a situation. There are 7 members of a family consisting of 6 adults and one child. They want to go to Dufan for a holiday. Does anyone want to try?

(Three students raised their hands and the teacher pointed two of them be a buyer and a seller)

L1: Oke, T5 is the ticket seller and T11 is the buyer.

S5: Hi, how many tickets do you want to buy?

S11: Six adults and one child to Dufan, please.

S5: All right, here they are. The total is eighty-five thousand rupiahs.

S11: Ok. (Pretending to give money)

S5: Thank you. Enjoy your day!

(Meeting 8, How to buy tickets)

\section{Excerpt 6}

(Teacher 2 shared screen some pictures about some places in Bengkulu)

L2: You can see four pictures on your screen. They are Zakat beach, Marlborough fort, Dendam Tak Sudah Lake, and Bung Karno's house. Now, take a look at the first picture. It is Marlborough fort. Have you ever been there?

Multiple-slot

Substitution Drill

Ss: Yes, I have (most of the students answered this loudly)

Ss: No, I am not. (The rest who have not been to the fort)

L2: I am not? 
Ss: I have not. No, I have not.

L2: Do you have any opinion about this picture?

S13: It is very unique and beautiful, mam.

L2: Does it look like an ancient building?

S4: Yes mam, it looks very ancient. Maybe because it is made by the British East India Company.

L2: Was it built by the British?

S4: Oh ya mam, it was built by the British. (Meeting 2, Describing places)

Question and Answer Drill

Question and Answer Drill

\section{Discussion}

According to Ballman and Larsen-Freeman (1988), there are seven types of drilling used in language learning. They are backward build-up or expansion drill, repetition drill, chain drill, single-slot substitution drill, multiple-slot substitution drill, transformation drill, and question and answer drill. From the two observations above, done in both classes, it was found that the teachers used four of seven types of drilling, such as repetition drill, single-slot substitution drill, multipleslot substitution drill, and question and answer drill.

In the classroom, the researchers observe that $\mathrm{T} 1$ frequently used repetition and substitution drilling in her class. It can be due to the level of students she taught, that is, semester one. While T2 is most likely to use substitution and question and answer drilling for semester three students.

In the observation result, (1) in repetition, the students repeated the utterance aloud as soon as the teacher finishes saying it. The utterance or words being practiced should be short so that the ear quickly catches them. (2) The teachers then applied substitution drills in teaching speaking to the students, either single-slot or multiple-slot substitution. In single-slot substitution, the teacher read a sentence, and the students repeated it and then called out a word that the students might fit into the sentence. (3) While in multiple-slot substitution, she called out two or more words. (4) Besides, she also used question-andanswer drills in the learning process. The teachers provide supervision of student responses. They should respond quickly to the teacher's questions. It is also possible for the teacher to provide practice for the students by asking them a question. This gives students opportunities to practice the same question style. 
Of the seven types of drills mentioned above, not all can be immediately applied in the English-speaking virtual classroom. The choice of the type of drill must be adjusted to the difficulty level of the teaching materials that will be given to students in stages.

From the data above, it can be seen that the teachers use various strategies to make the teaching and learning process run well in the classroom. They try to bring so many ways that they usually do in the face-to-face classroom to the virtual classroom. Nonetheless, it was a little bit hard for them to make sure whether the students understand or pay more attention in the class, especially for beginner students who suddenly have to experience online learning due to the pandemic. The teachers must design a thorough readiness to make students understand the materials being taught. Teachers' preparation in teaching a productive skill needs much effort. They have to take notes of the students' ability to speak one by one so that the teachers can adequately assess their progress.

The teacher also mentioned some weaknesses faced by teachers and students in this online class, for example, signal constraints when speaking through the zoom application and the inactivity of students in discussion groups if there was no lure with grades. The problem with this bad signal is that many students live in remote areas, so it is rather difficult for them to follow the lecture process. This is also one reason the teachers created Google classroom to handle this situation where the students can read the materials and submit their work in that App.

To put it briefly, the researchers found that both teachers implemented various strategies to manage their students to overcome their speaking skills difficulties, especially in the current situation, which drives the students and teachers to do the teaching and learning virtually. With different ways of teaching, both teachers seem to have the same pattern strategies. Based on Wehrli and Nyquist (2003), the researchers found that the teachers had carried out four of the ten teaching strategies (lecturing, role-play, discussion, and simulation) and one additional strategy (drilling) outside the guidelines used. Those strategies are quite well enough to affect the students' outcomes. Thenceforth, the teachers appreciated students' presence in taking part in lessons even in pandemic conditions like now. Both parties, indeed, must have more effort so that the learning objectives are achieved properly. 


\section{CONCLUSION}

The two teachers in this study implemented four of ten strategies suggested by Wehrli and Nyquist (2003) and one additional strategy in teaching speaking skills in the time of covid-19. They employed lecturing, role-play, online group discussion, simulation, and drilling. Those strategies are integrated with mobile applications and social media such as Zoom, WhatsApp Group, Google Classroom, and Instagram. Each of the applications helps the teachers deliver the materials conveyed to the students in the virtual class.

Although the condition requires the teachers and the students to meet in an online classroom, the learning process can run fair enough even though some obstacles are encountered. Another thing that must be changed from the student's point of view is student-self regulatory learning, which must be enhanced to be more active in the learning process. Thus, it is suggested for the next researcher to investigate students' opinions dealing with self-regulatory learning in the time of covid-19 in speaking class.

\section{REFERENCES}

Ballman, T. L., \& Larsen-Freeman, D. (1988). Techniques and Principles in Language Teaching. The Modern Language Journal, 72(2), 216. https://doi.org/10.2307/328245

Belecina, Rene R; Ocampo, J. J. (2018). Effecting Change on Students?? Critical Thinking in Problem Solving. Educare, 10(2), 109-118.

Brown, Douglas, H. (2000). Principles of Language Learning and Teaching. Pearson Longman.

Espino-d, L., \& Fernandez-caminero, G. (2020). Analyzing the Impact of COVID-19 on Education Professionals. Toward a Paradigm Shift : ICT and Neuroeducation as a Binomial of Action. 1-10.

Foshay, A. . (1975). Teaching Tactics, Teaching Strategy. Educational Leadership, 3, 373-375.

Gao, F. (2014). Exploring the use of discussion strategies and labels in asynchronous online discussion. Journal of Asynchronous Learning Network, 18(3), 1-19. https://doi.org/10.24059/olj.v18i3.460

Gusmuliana, P., Apriani, E., \& Syafryadin, S. (2021). Improving Students 
Speaking Motivation by Using Role Play Technique at Institute Islamic in Indonesia.

Hadi, M. S. (2015). Games as The Strategy in Teaching Speaking for Young Learners. June 2015.

Kaur, G. (2011). Study and Analysis of Lecture Model of Teaching. 1(1), 913.

King, F. B. (2001). Defining Distance Learning and Distance Education. January.

Kistner, S., Rakoczy, K., Otto, B., \& Klieme, E. (2015). Teaching learning strategies: The role of instructional context and teacher beliefs. Journal for Educational Research Online, 7(1), 176-197. http://www.j-e-r-

o.com/index.php/jero/article/download/542/228

Mishra, L., Gupta, T., \& Shree, A. (2020). International Journal of Educational Research Open Online teaching-learning in higher education during lockdown period of COVID-19 pandemic. International Journal of Educational Research Open, 1(August), 100012. https://doi.org/10.1016/j.ijedro.2020.100012

Moerti, W. (2021). Data Terkini Covid-19 di Indonesia Januari 2021. Merdeka.Com. https://www.merdeka.com/peristiwa/data-terkinicovid-19-di-indonesia-januari-2021.html

Naser, A., \& Almutairi, M. (2015). The Effect of Using Brainstorming Strategy in Developing Creative Problem-Solving Skills among male Students in Kuwait : A Field Study on Saud Al-Kharji School in Kuwait City. 6(3), 136-146.

Nassaji, H. (2015). Qualitative and descriptive research: Data type versus data analysis. Language Teaching Research, 19(2), 129-132. https://doi.org/10.1177/1362168815572747

Saykill, A. (2018). Distance Education: Definitions, Generations, Key Concepts, and Future Directions. International Journal of Contemporary Educational Research, 5(1), 1-17.

Syafryadin, S., Chandra, W. D. E., Apriani, E., \& Noermanzah, N. (2020). Maxim Variation, Conventional, And Particularized Implicature On Students' Conversation. International Journal of Scientific and Technology of Research, 9(02), 3270-3274.

Syahrial, Asrial, Kurniawan, D. A., \& Subandiyo, M. (2019). Pedagogic 
competence and Indonesian language competence pre-service teacher of the elementary program. International Journal of Scientific and Technology Research, 8(10), 851-856.

Taufik, M., Rijal, A. S., Dahniar, D., \& Apriani, E. (2021). The Effectiveness of Learning English Using LMS Google Classroom during the Covid19 Pandemic. AL-ISHLAH: Jurnal Pendidikan, 13(2), 960-970.

Vlachopoulos, D., \& Makri, A. (2017). The effect of games and simulations on higher education: a systematic literature review. In International Journal of Educational Technology in Higher Education (Vol. 14, Issue 1). International Journal of Educational Technology in Higher Education. https://doi.org/10.1186/s41239-017-0062-1

Wehrli, G., \& Nyquist, J. (2003). Creating an educational curriculum for learners at any level. $A A B B$ Conference. Retrieved from http://www.tulane.edu/som/ome/upload/ComparisonOfTeaching Methodologies.pdf 
276 | ENGLISH FRANCA, Vol. 5, No. 2, 2021 